\title{
Validation of Modified Soft Skills Assessment Instrument (MOSSAI) for Use in Nigeria
}

\author{
O.A. Aworanti", M.B. Taiwo, O. I. Iluobe \\ National Business and Technical Examinations Board (NABTEB), Nigeria
}

Copyright $(\mathcal{C} 2015$ by authors, all rights reserved. Authors agree that this article remains permanently open access under the terms of the Creative Commons Attribution License 4.0 International License

\begin{abstract}
Currently, it has become an accepted norm nearly all over the globe to teach and assess soft skills. However, in Nigeria, it is an emerging area of interest that needs to be addressed squarely. In the light of the fore-going, this study validated a modified version of Measuring and Assessment Soft Skills (MASS) (an instrument developed and used by twenty European researchers from five countries), for use in the Nigeria setting. It was administered on a randomly selected sample from the northern and southern parts of Nigeria. Survey design was used in the study. The 15-point instrument was administered on 600 participants each from the Northern and Southern parts of Nigeria with a total of 1,200 participants. This instrument also included method for teaching and assessing soft skills. Factor analysis was used to analyze the data in Section B of the instrument, mean and standard deviation for Sections $\mathrm{C}$ and $\mathrm{D}$. The results show that the soft skills needed to enhance performances in workplaces are teachable and examinable in Nigeria. It was, therefore, recommended that examining bodies should consider adopting or adapting the instrument for use in the Sub-Saharan Africa.
\end{abstract}

Keywords Soft Skills, Teaching of Soft Skills, Soft Skills Assessment, and Strategies for Assessing Soft Skills

\section{Introduction}

There is no doubt that there are skills and abilities necessary for success in life. Such skills and behavioural competences are often latent in nature, yet they are required to achieve success in life endeavours. Hence, the term "soft skill" is used to differentiate these skills and innate abilities from technical or hard skills which are learnt. Shakir [1] described soft skills as non academic skills in the form of leadership, team work, communication and life- long learning. Education Equals Economics (E3) Alliance [2] asserted that soft skills is a set of skills, abilities and traits that pertain to personality, attitude and behaviours rather than formal technical knowledge. Kechagias [3] expressed soft skills as intra and inter-personal or socio-emotional skills essential for personal development, social participation and workplace success. They include such skills as ability to work on multi-disciplinary teams, effective communication, cultural awareness and expression, diligence, adaptability and honesty among others.

To Bunk [4], the typology of soft skills could be explained from three major perspectives. These include the capacity for social adaptation, disposition for cooperation, and team spirit. Nabi [5] classified soft skills into personal skills, communication skills and problem-solving skills. Crosbie [6] identified eight soft skills needed by the individuals in workplace which include collaboration/teamwork, communication skills, initiative, leadership ability, people development/coaching, personal effectiveness/personal mastery, planning, organizing and presentation skills.

Similarly, Kechagias [3] asserted that soft skills could be summarized into a series of twenty skills which are categorized into four general blocks: emotional self-awareness, self-management or self-government (self-control), social awareness (empathy), and management of social relations skills. These typologies were later reviewed by some scholars with a list of fifteen most important socio-emotional dimensions (of soft skills) which include: adaptability, assertiveness, emotional assessment of oneself and of others, emotional expression, emotional management of others, emotional regulation, low impulsiveness, the skills required to form relationships, self-esteem, self-motivation, social skills, stress management, empathy, happiness and optimism.

The importance of such skills in personal development for effective performance of one's task has necessitated the advocacy for the teaching and assessing of soft skills in a formal school setting. Gordon et al. [7] identified a range of rationales for focusing on soft skills development which include learner's empowerment, preparing worker for the labour market, supporting learner in becoming an effective citizen as well as an effective parent/family member to live respectively in a culturally diverse society and to promote environmental awareness. Interestingly, this underlying purpose affects the aim, teaching methods, power dynamics between teacher and learner, the areas to be assessed and how assessment is to be done.

Aworanti [8] opined that some forms of soft skills, that could be realized are inherent in every individual. As an individual, it is expected in a workplace to relate well with 
others, be passionate to encourage others and handle various challenges. No wonder a lot of companies today do not only assess their current staff and future recruits on their business skills but are more interested in assessing them on the various aspects of soft skill competencies with a view to knowing the extent they relate and communicate with others. Incorporating soft skills into the school system, Lee et al [9] opined that the teacher needed to create a positive culture that would encourage students' learning achievement. Such classroom culture should be geared towards generating students' friendly relationships, appreciating students' achievements, creating interesting learning experiences and developing leadership and sense of duty among others

Kechagias [3] identified two different schools of thought in the teaching of soft skills. These are the 'generalists' and the 'specifists'. To the generalists, soft skills are seen as generic which can be taught separately from content and applied to any discipline. However the specifists believed that soft skills could not be taught as one-shot inoculation of skill development but to be embedded in each course or subject since knowledge is fundamentally situated. In consonance with these approaches, twenty European researchers (3 from UK, 5 from Greece, 4 from Sweden, 3 from Romania and 5 from Netherlands) described the teaching approaches as "Autonomous Teaching" or "Stand-Alone Approach" and "Intermixed Teaching" or "Embedded Approach".

A fifteen-item soft skills assessment instrument was developed by these twenty European researchers which later formed the basis for the assessment of soft skills in Europe. The fifteen-item soft skills assessment include: manners, ownership of tasks, attendance, motivation, professionalism, work output, conduct in workplace, time keeping, verbal communication, organization/planning, team working/respect, helping others, conscientiousness, ability to ask for help and adaptability/flexibility. It is obvious that what works in one place may not necessarily work in another, perhaps as a result of socio-cultural differences. This invariably, calls for adaptation, so that such thing can also work in a different setting, hence, the need of revalidation of instrument for use in Nigeria.

\section{Statement of Problem}

Despite the popularity of teaching and assessment of soft skills in the Western world, the integration of the concept of soft skills in African school setting is yet to be fully embraced. Some African scholars see soft skills as being innate to be taught and examined while others believed they are teachable but not examinable. Another impediment to the formalization of socio-emotional skills education is getting appropriate methods for the teaching and assessment of soft skills. This paper is aimed at seeking the stakeholders' views on the appropriate methods for teaching and assessing soft skills in Nigerian educational system. This paper, therefore, validated a modification of the instrument developed by the European researchers for the measuring and assessment of soft skills (MASS) in Europe and also investigated its usability in the Nigerian context.

\section{Research Questions}

To address the problem identified on MASS by some African educational researchers, the following two questions have been raised for this study:

1. What is the exploratory factor model of the Modified Assessment of Soft Skills Instrument (MOSSAI)?

2. Is the Modified Soft Skills Assessment Instrument (MOSSAI) adaptable to the teaching and assessment methods used in Nigerian Schools?

\section{Methodology}

The study was designed as a survey. The population of the study was made up of teaching personnel from both the private and public schools registered by the National Business and Technical Examinations Board (NABTEB), Nigeria. Multi-stage sampling technique was adopted in selecting 1,200 respondents for this study. Out of six geo-political zones in Nigeria, four were randomly selected that is, two geopolitical zones each from northern and southern parts. Two states were randomly selected from each of the four geopolitical zones. In each of the states, six schools of both public and private were randomly selected with 25 participants each. Thus, a total of forty-eight schools were used comprising thirty-five (35) technical schools (public) and thirteen (13) private schools with 825 and 375 participants respectively. Thus, there were 683 male teachers and 517 female teachers' altogether.

\section{Instrumentation}

Based on the 15-point Measuring and Assessment of Soft Skills (MASS) designed which formed the basis of the study (Appendix I for details), the researchers drafted 63 variables to form the Modified Soft Skills Assessment Instrument (MOSSAI) for the use in Nigeria (See appendix II for details). Section A of the MOSSAI has to do with personal data of the respondents in terms of name of school and gender. The 63 variables formed Section B of the new instrument for this study while Sections C and D focused on methods of teaching and assessing soft skills.

\section{Analysis Procedure}

The statistics employed for analysis of the data obtained from Section B of the instrument was Exploratory Factor Analysis (EFA) for validity coupled with Cronbach Alpha for reliability. The initial reliability of the 63 variables was 0.968 which underwent factor analysis process with orthogonal rotation to produce 5 -factor model of 50 content areas for final version (See Appendix III for details) The reliability of the final version was 0.961 .The names given to the subscales of the 5 -factor model with their reliability coefficients are commitment to duty (0.908), attending to responsibilities (0.925), adaptability (0.901), resources management skills (0.801) and motivation (0.791). For Sections C and D of the MOSSAI, mean and standard deviation were used to analyze the responses of the respondents. Data from a mean of 2.5 and above were accepted while others below 2.5 were rejected. 


\section{Results and Findings}

\section{Research Question 1}

What is the exploratory factor model of the Modified Soft Skills Assessment Instrument (MOSSAI)?

Table 1a. Table Showing the Communalities of the Extracted Factors

\begin{tabular}{|c|c|c|}
\hline Variable & Initial & Extraction \\
\hline var1 & .560 & .629 \\
\hline var2 & .356 & .330 \\
\hline var3 & .402 & .358 \\
\hline var4 & .405 & .364 \\
\hline var5 & .457 & .416 \\
\hline var6 & .467 & .466 \\
\hline var7 & .398 & .365 \\
\hline var8 & .460 & .460 \\
\hline var9 & .426 & .404 \\
\hline var10 & .406 & .384 \\
\hline var11 & .593 & .842 \\
\hline var12 & .405 & .396 \\
\hline var13 & .500 & .577 \\
\hline var14 & .468 & .566 \\
\hline var15 & .432 & .455 \\
\hline var16 & .399 & .334 \\
\hline var17 & .508 & .491 \\
\hline var18 & .531 & .466 \\
\hline var19 & .535 & .448 \\
\hline var20 & .805 & .864 \\
\hline var21 & .443 & .411 \\
\hline var22 & .471 & .384 \\
\hline var23 & .535 & .474 \\
\hline var24 & .386 & .337 \\
\hline var25 & .463 & .448 \\
\hline var26 & .429 & .389 \\
\hline var27 & .516 & .613 \\
\hline var28 & .538 & .586 \\
\hline var29 & .411 & .380 \\
\hline var30 & .485 & .514 \\
\hline var31 & .500 & .608 \\
\hline var32 & .524 & .566 \\
\hline var33 & .465 & .440 \\
\hline var34 & .535 & .566 \\
\hline var35 & .628 & .681 \\
\hline var36 & .564 & .576 \\
\hline var37 & .579 & .582 \\
\hline var38 & .591 & .592 \\
\hline var39 & .513 & .499 \\
\hline var40 & .512 & .448 \\
\hline var41 & .507 & .443 \\
\hline var42 & .562 & .542 \\
\hline var43 & .546 & .554 \\
\hline var44 & .488 & .538 \\
\hline var45 & .552 & .517 \\
\hline var46 & .560 & .554 \\
\hline var47 & .539 & .555 \\
\hline var48 & .465 & .466 \\
\hline var49 & .582 & .531 \\
\hline var50 & .565 & .526 \\
\hline var51 & .588 & .599 \\
\hline
\end{tabular}




\begin{tabular}{|c|c|c|}
\hline & .589 & .647 \\
\hline var52 & .531 & .580 \\
\hline var53 & .507 & .493 \\
\hline var54 & .579 & .577 \\
\hline var55 & .532 & .550 \\
\hline var56 & .521 & .514 \\
\hline var57 & .486 & .469 \\
\hline var58 & .525 & .512 \\
\hline var59 & .577 & .590 \\
\hline var60 & .623 & .614 \\
\hline var61 & .606 & .555 \\
\hline var62 & .812 & .907 \\
\hline
\end{tabular}

Table 1b. Kaiser-Meyer-Olkin (KMO) and Bartlet's Test

\begin{tabular}{|lc|c|}
\hline & Kaiser-Meyer-Olkin Measure of Sampling Adequacy. & .965 \\
Bartlett's Test of Sphericity & Approx. Chi-Square & 40692.753 \\
& Df & 1953 \\
\hline
\end{tabular}

Table 1c. Total Variance Explained

\begin{tabular}{|c|c|c|c|c|c|c|c|c|c|}
\hline Factor & \multicolumn{3}{|c|}{ Initial Eigenvalues } & \multicolumn{3}{|c|}{ Extraction Sums of Squared Loadings } & \multicolumn{3}{|c|}{ Rotation Sums of Squared Loadings } \\
\hline & Total & $\begin{array}{c}\% \text { of } \\
\text { Variance }\end{array}$ & $\begin{array}{c}\text { Cummulative } \\
\%\end{array}$ & Total & $\begin{array}{c}\% \text { of } \\
\text { Variance }\end{array}$ & $\begin{array}{c}\text { Cummulative } \\
\%\end{array}$ & Total & $\begin{array}{c}\% \text { of } \\
\text { Variance }\end{array}$ & Cummulative $\%$ \\
\hline 1 & 21.416 & 33.994 & 33.994 & 20.495 & 32.531 & 32.531 & 7.784 & 12.356 & 12.356 \\
\hline 2 & 3.234 & 5.133 & 39.127 & 2.088 & 3.314 & 35.845 & 7.047 & 11.185 & 23.541 \\
\hline 3 & 2.525 & 4.008 & 43.135 & 2.307 & 3.661 & 39.506 & 4.827 & 7.662 & 31.204 \\
\hline 4 & 1.649 & 2.617 & 45.753 & 1.611 & 2.557 & 42.063 & 2.466 & 3.914 & 35.118 \\
\hline 5 & 1.564 & 2.483 & 48.236 & 1.427 & 2.265 & 44.329 & 1.915 & 3.040 & 38.158 \\
\hline 6 & 1.332 & 2.115 & 50.351 & .978 & 1.553 & 45.882 & 1.791 & 2.842 & 41.000 \\
\hline 7 & 1.295 & 2.056 & 52.407 & .907 & 1.439 & 47.321 & 1.617 & 2.566 & 43.566 \\
\hline 8 & 1.185 & 1.881 & 54.288 & .833 & 1.322 & 48.644 & 1.549 & 2.458 & 46.025 \\
\hline 9 & 1.123 & 1.782 & 56.070 & .687 & 1.091 & 49.735 & 1.541 & 2.446 & 48.471 \\
\hline 10 & 1.091 & 1.731 & 57.801 & .641 & 1.018 & 50.753 & 1.332 & 2.114 & 50.585 \\
\hline 11 & 1.044 & 1.657 & 59.458 & .568 & .902 & 51.655 & .674 & 1.070 & 51.655 \\
\hline 12 & .966 & 1.533 & 60.991 & & & & & & \\
\hline 13 & .934 & 1.482 & 62.473 & & & & & & \\
\hline 14 & .858 & 1.363 & 63.836 & & & & & & \\
\hline 15 & .832 & 1.321 & 65.156 & & & & & & \\
\hline 16 & .807 & 1.281 & 66.437 & & & & & & \\
\hline 17 & .791 & 1.256 & 67.693 & & & & & & \\
\hline 18 & .745 & 1.183 & 68.876 & & & & & & \\
\hline 19 & .713 & 1.132 & 70.008 & & & & & & \\
\hline 20 & .703 & 1.116 & 71.124 & & & & & & \\
\hline 21 & .699 & 1.110 & 72.233 & & & & & & \\
\hline 22 & .691 & 1.096 & 73.330 & & & & & & \\
\hline 23 & .652 & 1.035 & 74.365 & & & & & & \\
\hline 24 & .629 & .998 & 75.362 & & & & & & \\
\hline 25 & .625 & .992 & 76.355 & & & & & & \\
\hline 26 & .603 & .957 & 77.311 & & & & & & \\
\hline 27 & .589 & .935 & 78.246 & & & & & & \\
\hline 28 & .576 & .914 & 79.160 & & & & & & \\
\hline 29 & .570 & .905 & 80.065 & & & & & & \\
\hline 30 & .550 & .874 & 80.938 & & & & & & \\
\hline 31 & .532 & .844 & 81.782 & & & & & & \\
\hline 32 & .522 & .829 & 82.611 & & & & & & \\
\hline 33 & .513 & .814 & 83.425 & & & & & & \\
\hline 34 & .494 & .784 & 84.209 & & & & & & \\
\hline 35 & .485 & .770 & 84.979 & & & & & & \\
\hline 36 & .483 & .767 & 85.746 & & & & & & \\
\hline 37 & .474 & .753 & 86.499 & & & & & & \\
\hline 38 & .472 & .749 & 87.248 & & & & & & \\
\hline
\end{tabular}




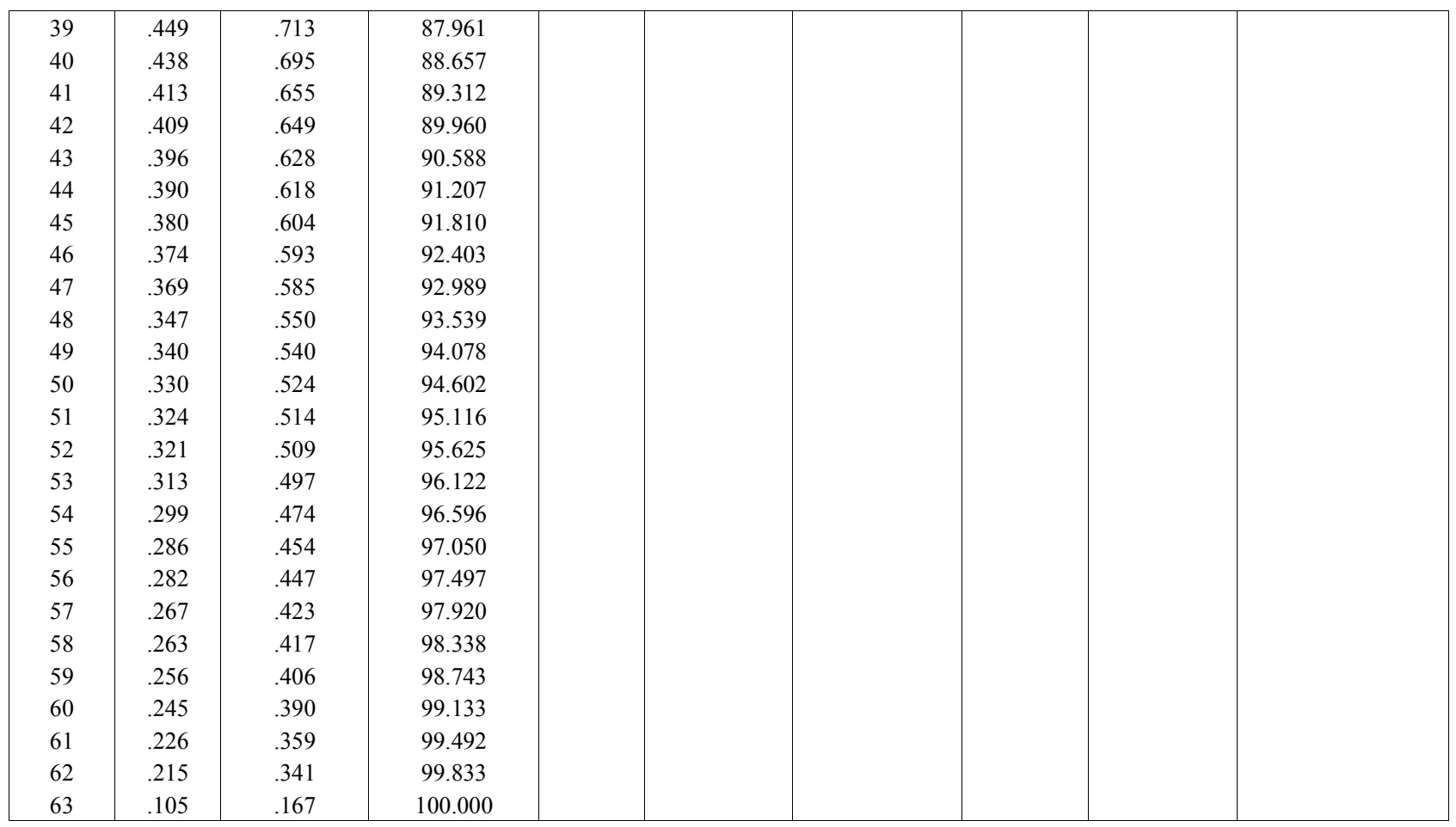

Extraction Method: Maximum Likelihood

\section{Scree Plot}

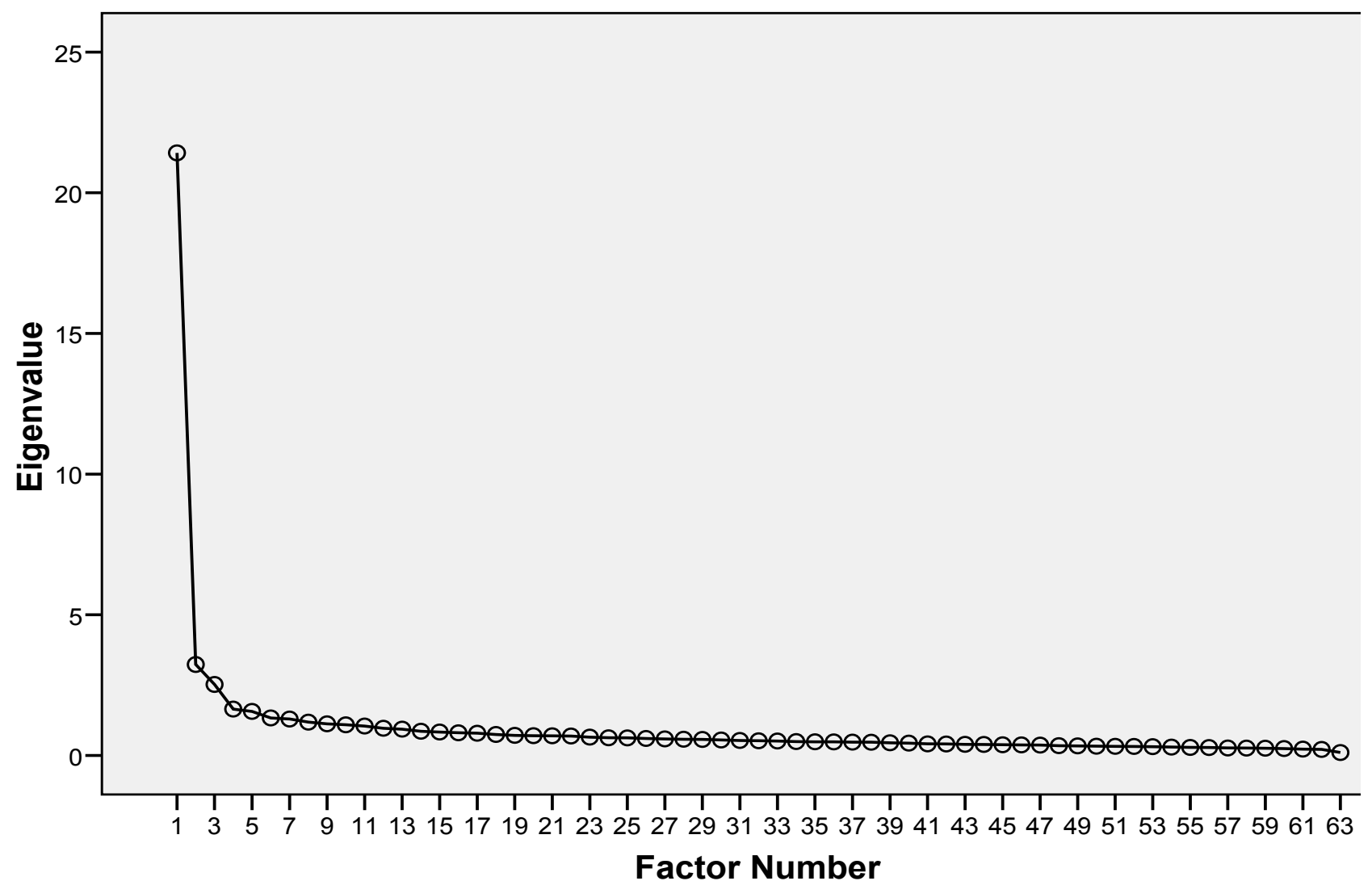

Figure 1. The Scree Plot 
Table 1d. Table Showing the Rotated Factor Matrix

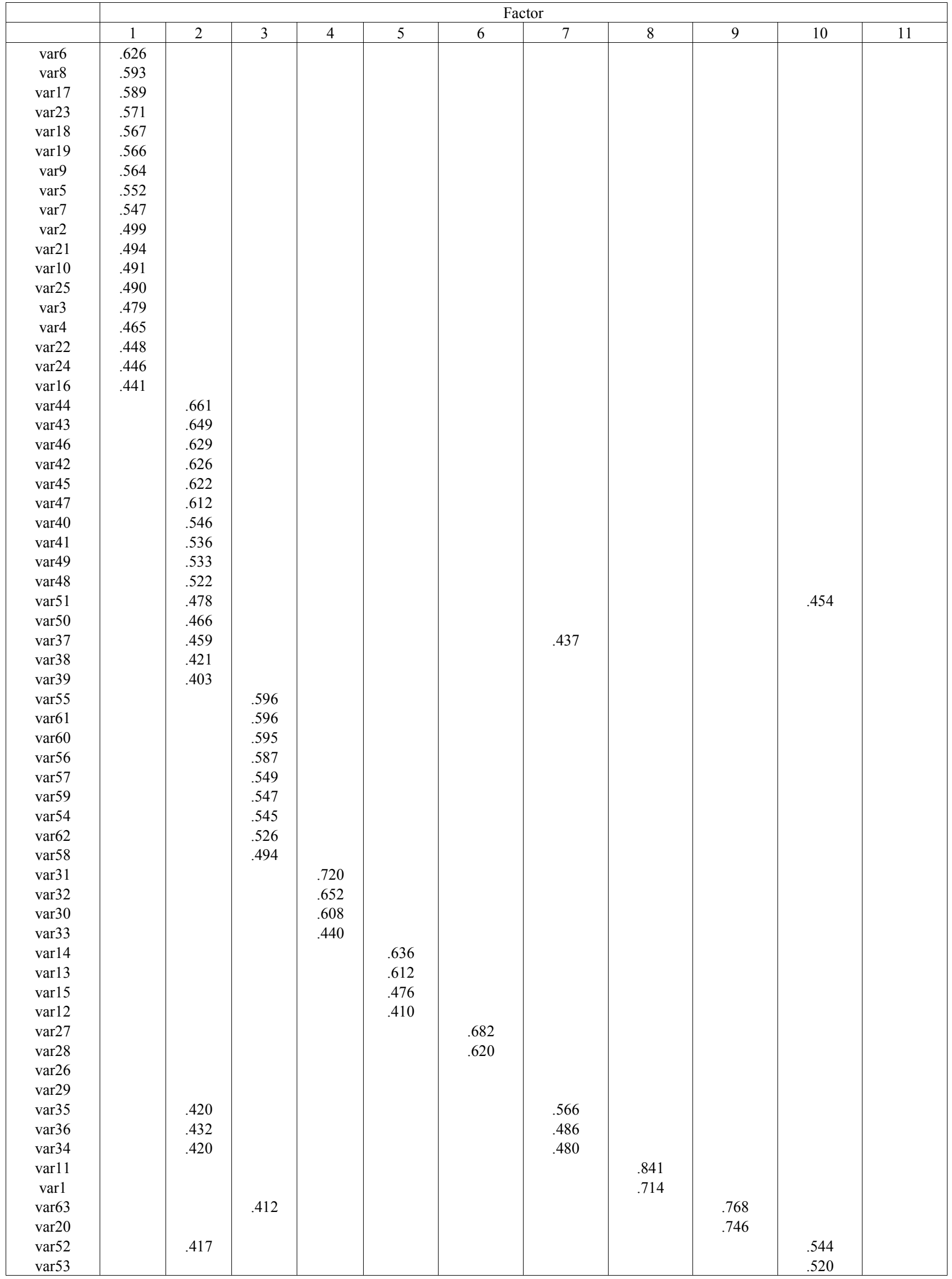


Table 1e. Table showing factor loading for rotated factors, eigenvalues and percentage of the five-factor model in new MOSSAI

\begin{tabular}{|c|c|c|c|c|c|c|}
\hline \multirow{2}{*}{ Item No } & \multicolumn{5}{|c|}{ Factor } & \multirow[t]{2}{*}{ Final Communality Estimate } \\
\hline & 1 & 2 & 3 & 4 & 5 & \\
\hline 1 & .63 & & & & & .466 \\
\hline 2 & .59 & & & & & .460 \\
\hline 3 & .59 & & & & & .491 \\
\hline 4 & .57 & & & & & .474 \\
\hline 5 & .57 & & & & & .466 \\
\hline 6 & .57 & & & & & .448 \\
\hline 7 & .56 & & & & & .404 \\
\hline 8 & .55 & & & & & .416 \\
\hline 9 & .55 & & & & & .365 \\
\hline 10 & .50 & & & & & .330 \\
\hline 11 & .50 & & & & & .411 \\
\hline 12 & .49 & & & & & .384 \\
\hline 13 & .49 & & & & & .448 \\
\hline 14 & .48 & & & & & .358 \\
\hline 15 & .47 & & & & & .364 \\
\hline 16 & .45 & & & & & .384 \\
\hline 17 & .45 & & & & & .337 \\
\hline 18 & & .66 & & & & .334 \\
\hline 19 & & .65 & & & & .538 \\
\hline 20 & & .63 & & & & .554 \\
\hline 21 & & .63 & & & & .554 \\
\hline 22 & & .62 & & & & .542 \\
\hline 23 & & .61 & & & & .517 \\
\hline 24 & & .55 & & & & .555 \\
\hline 25 & & .54 & & & & .448 \\
\hline 26 & & .53 & & & & .443 \\
\hline 27 & & .52 & & & & .531 \\
\hline 28 & & .48 & & & & .466 \\
\hline 29 & & .47 & & & & .599 \\
\hline 30 & & .46 & & & & .526 \\
\hline 31 & & .42 & & & & .582 \\
\hline 32 & & .40 & & & & .592 \\
\hline 33 & & & .60 & & & .499 \\
\hline 34 & & & .60 & & & .577 \\
\hline 35 & & & .60 & & & .614 \\
\hline 36 & & & .59 & & & .590 \\
\hline 37 & & & .55 & & & .550 \\
\hline 38 & & & .55 & & & .514 \\
\hline 39 & & & .55 & & & .512 \\
\hline 40 & & & .53 & & & .493 \\
\hline 41 & & & .49 & & & .555 \\
\hline 42 & & & & .72 & & .469 \\
\hline 43 & & & & .65 & & .608 \\
\hline 44 & & & & .61 & & .566 \\
\hline 45 & & & & .44 & & .514 \\
\hline 46 & & & & & .64 & .440 \\
\hline 47 & & & & & .61 & .566 \\
\hline 48 & & & & & .48 & .577 \\
\hline 49 & & & & & .41 & .455 \\
\hline 50 & & & & & .64 & .396 \\
\hline Eigenvalues & 21.416 & 3.234 & 2.525 & 1.649 & 1.564 & \\
\hline Percentage of variance & 33.994 & 5.133 & 4.008 & 2.617 & 2.483 & \\
\hline
\end{tabular}


Table (1a) presents the Table of Communalities before and after extraction which indicates how much variance in each variable of this study is explained by the analysis. Table (1b) shows Kaiser-Meyer-Olkin (KMO) Measure of Sampling Adequacy. As a measure of factorability, the KMO is 0.965 . The Bartlett's Test of Sphericity indicates that the data is probably factorable and it is significant $(\mathrm{p}<.05)$. Table (1c) depicts the total variance for factor solution in this study. The table presents the eigenvalues before extraction and after rotation to have sums of squared loadings and rotation sums of squared loadings respectively. In this study, the first eleven factors with eigenvalues is greater than 1 accounted for $51.7 \%$. Figure (1) presents the Scree Plot which is the graph of how the eigenvalues coordinates with the factors. Table (1d) shows rotated factor matrix while Table (1e) presents factor loading for rotated factors, eigenvalues and percentage of the five-factor model in the new instrument (MOSSAI).

\section{Discussion}

Having considered the basic steps for retaining the reliable factors by means of eigenvalues, amount of total variance, scree plot, residuals and assessment of model fit in the Modified Soft Skills Assessment Instrument (MOSSAI), 11 variables have eigenvalues that exceeded the criterion value of 1.00 . The feasibility of at least $70 \%$ of the total variability was not attained due to the sample size. However, the total variance accounted for was $51.7 \%$. The Scree Plot at its sharp bent in relation to eigenvalues produced was inspected; the rotated factor matrix yielded a 5-factor result. As a function of factor analysis, the correlation coefficient between observed and reproduced coefficients determines the residual for achieving the fit of the model created by the factors. Due to the enlargement of the table of reproduced coefficient, the footnote produced by SPSS package shows that there are $48(2.0 \%)$ non-redundant residuals with absolute values greater than 0.05 . By implication, the model for this study has a good fit. The steps for retaining reliable factors validate Kerlinger et al. [10] and Mertler et al. [11] which stated that only those components (factors) whose eigenvalues are greater than 1 should be retained; they explained further that amount of total variance, the scree plot as well as residual for achieving the model fit are part of the essential factors for consideration.

The identified 5-factor in this study has been interpreted as commitment to duty, attending to responsibilities, adaptability, resources management skills and motivation for clarity and proper identification purposes.

\section{Research Question 2}

Is the Modified Soft Skills Assessment Instrument (MOSSAI) adaptable to the teaching and assessment methods used in Nigerian Schools?

Table 2a. Mean rating and standard deviation of methods of teaching soft skills

\begin{tabular}{|c|c|c|c|c|}
\hline S/N & METHODS OF TEACHING SOFT SKILLS & MEAN & STANDARD DEVIATION & REMARK \\
\hline 1. & Direct instruction & 2.52 & .603 & Accept \\
\hline 2. & Demonstration method & 2.57 & .574 & Accept \\
\hline 3. & Lecture method & 2.19 & .747 & Reject \\
\hline 4. & Discussion method & 2.72 & .699 & Accept \\
\hline 5. & Simulation method & 2.50 & .625 & Accept \\
\hline 6 & Rote memorization & 2.16 & .759 & Reject \\
\hline .7. & Self discovery method & 2.52 & .656 & Accept \\
\hline 8. & Questioning method & 2.51 & .639 & Accept \\
\hline 9. & Interviewing method & 2.54 & .644 & Accept \\
\hline 10. & Project approach & 2.52 & .661 & Accept \\
\hline 11. & Mapping method & 2.11 & .688 & Reject \\
\hline 12. & Cooperative learning & 2.54 & .622 & Accept \\
\hline 13. & Reflection & 2.51 & .662 & Accept \\
\hline 14. & Pictorial method & 2.38 & .681 & Reject \\
\hline
\end{tabular}

Table 2b. Mean rating and standard deviation of methods of assessing soft skills

\begin{tabular}{|c|c|c|c|c|}
\hline S/N & METHODS OF ASSESSING SOFT SKILLS & MEAN & STANDARD DEVIATION & REMARK \\
\hline 1. & Objective tests & 2.53 & .616 & Accept \\
\hline 2. & Essay tests & 2.55 & .594 & Accept \\
\hline 3. & Practical tests & 2.59 & .598 & Accept \\
\hline 4. & Speed tests & 2.10 & .726 & Reject \\
\hline 5. & Checklists & 2.51 & .660 & Accept \\
\hline 6. & Questionnaires & 2.53 & .674 & Accept \\
\hline 7. & Interviews & 2.25 & .693 & Reject \\
\hline 8. & Rating scales & 2.52 & .656 & Accept \\
\hline 9. & Observations & 2.55 & .635 & Accept \\
\hline 10. & Portfolios & 2.04 & .733 & Reject \\
\hline 11. & Assignments & 2.47 & .644 & Accept \\
\hline
\end{tabular}


Table (2a) overleaf depicts the responses of the respondents toward appropriate methods of teaching soft skills in the new instrument. Out of the fourteen perceived methods, only ten were approved by the respondents for this study. In terms of rating, the highest rated method of teaching is the discussion method with a mean of 2.71 and standard deviation of 0.699 while the least rated one is the simulation method which has a mean of 2.50 and standard deviation of 0.625 . From Table ( $2 b)$, out of eleven perceived methods of assessing soft skills, eight were accepted. Practical tests is the most rated assessment method with a mean of 2.59 and standard deviation of 0.598 while the least rated is assignment with a mean of 2.47 and standard deviation of 0.644 .

The findings revealed agreement among respondents on certain appropriate teaching and assessment methods for soft skills in the new instrument. Such teaching methods include: discussion, demonstration, interviewing, direct instruction, self discovery, project approach, cooperative learning, questioning, reflection and simulation. To encourage latent traits in an individual for achieving success in life, soft skills require different teaching methods for self-awareness.

In the same vein, assessment methods favoured are practical tests, essay tests, observations, objective tests, questionnaires, rating scales, checklists, and assignments. These assessment methods agree with the studies of Curtis [12] and Kechagias [3] who categorize soft skills assessment methods into standardized assessment (multiple-choice or short-structured items provided for examinees' responses), common assessment tasks (where tasks designed to provide opportunities for examinees to demonstrate and/or develop constructs intended to be assessed), performance assessments types of testing that call for demonstration of understanding and skill in applied, procedural or open-ended settings), teacher/holistic judgment (where thorough, frequent and close observation of the teacher or supervisor is required) and portfolio assessment (where individual examinee is made to select and aggregate the evidence of his own achievement of particular skills).

\section{Conclusions}

In this paper, efforts have been made to examine the teachability and examinability of modified soft skills in Nigeria. The results in this study have shown that out of the fifteen identified soft skills by the five European countries, only five are suitable to be taught and examined in Nigerian context. These include commitment to duty, attending to responsibilities, adaptability, resources management skills and motivation. The study was able to identify fifty content areas that could be taught under the five concepts.

Based on the findings, the five soft skills have been proven teachable using such methods like direct instruction, demonstration, discussion, simulation, self discovery, questioning, interviewing, project, cooperative learning and reflection methods. In the same manner, the study revealed that the five-factor already identified can be examined using objective tests, essay tests, practical tests, checklists, questionnaires, rating scales, observations and assignments. Other methods including speed tests, interviews and portfolios are inappropriate and unsuitable for the examination of soft skills in Nigerian school system.

\section{Recommendations}

The design and development of Modified Soft Skills Assessment Instrument (MOSSAI) materials on the five teachable and examinable areas are recommended to be given a considerable attention while the Nigerian Educational Research and Development Council (NERDC) should design curriculum for the soft skills as a subject covering the fifty content areas identified in this study. Policy makers, school authorities, teachers, stakeholders and the general public should be sensitized on the need to commence teaching and assessing of soft skills in our educational system. Examination bodies in Africa should start thinking of examining/assessing soft skills as part of their examinable subjects. To reduce security threats and stop unnecessary killings in our continent, there is need for the introduction of soft skills in the primary, secondary and tertiary institutions. Following these arrangements, Nigeria and indeed other countries in Sub-Sahara Africa are encouraged to introduce soft skills in their teaching curricular. 


\section{Appendix I: Soft Skills Included in the Assessment of Soft Skills (Mass) Materials by 20 Europeans Researchers}

\begin{tabular}{|c|c|c|}
\hline Soft Skill & Other words that mean the same thing & Examples of when this soft skill is used \\
\hline Manners & Politeness, consideration, courtesy & $\begin{array}{l}\text { Saying thank you, holding doors open for others, asking } \\
\text { permission to do things etc }\end{array}$ \\
\hline Ownership of tasks & Responsibility, duty, dependability & $\begin{array}{l}\text { Making sure tasks are done properly, turning up on time for } \\
\text { meetings, working in partnership with others and doing your } \\
\text { role so they can do theirs etc }\end{array}$ \\
\hline Attendance & Turning up, coming in, appearing & $\begin{array}{l}\text { Arriving on time for meetings and for work. Making sure you } \\
\text { keep people informed regarding your attendance or availability. }\end{array}$ \\
\hline Motivation & Incentive, inspiration, drive, impulse & $\begin{array}{c}\text { Taking on new challenges, working hard to achieve goals, } \\
\text { thinking of new ways to do things }\end{array}$ \\
\hline Professionalism & Competent, skilful, dedicated & $\begin{array}{l}\text { Working to a high standard, being consistent in attitude (not } \\
\text { allowing emotions or personalities to influence you) }\end{array}$ \\
\hline Work output & Activity, productivity, production & $\begin{array}{l}\text { Meeting deadlines and standards for work. Producing products } \\
\text { to target. }\end{array}$ \\
\hline Conduct in workplace & Behaviour, attitude, maturity & $\begin{array}{l}\text { Respecting others, not playing games when you should be } \\
\text { working etc }\end{array}$ \\
\hline Timekeeping & On time, not late & Arriving for work or meetings on time, leaving at the right time \\
\hline Verbal Communication & Talking, Consulting, meetings, discussing & $\begin{array}{l}\text { Using the right tone of voice and words when speaking with } \\
\text { colleagues etc }\end{array}$ \\
\hline Organisation/ planning & Preparation, scheduling, arranging & $\begin{array}{l}\text { Having all required resources to hand, thinking jobs through, } \\
\text { arriving on time, meeting deadlines etc }\end{array}$ \\
\hline Team-working/ Respect & $\begin{array}{l}\text { Esteem, valuing others, helping others, } \\
\text { consideration }\end{array}$ & $\begin{array}{l}\text { Working well together on a task, making best use of your skills } \\
\text { and the skills of others. Acknowledge the status of others and } \\
\text { act accordingly }\end{array}$ \\
\hline Helping others & Supporting, offering, training & $\begin{array}{l}\text { Giving up some of your time to support those who are } \\
\text { struggling or need help to meet a deadline }\end{array}$ \\
\hline Conscientiousness & Careful, meticulous, thorough, hard working & $\begin{array}{l}\text { Paying attention to detail, accurate work, making sure you do } \\
\text { what you are paid to do }\end{array}$ \\
\hline $\begin{array}{l}\text { Ability to ask } \\
\text { for help }\end{array}$ & Admitting own limitations, confidence, courage & $\begin{array}{c}\text { Asking colleagues to show you how to do something or to help } \\
\text { you complete a task on time etc }\end{array}$ \\
\hline Adaptability/ Flexibility & Compliance, accepting change & $\begin{array}{l}\text { Taking on new challenges, accepting changes to rules and } \\
\text { conditions, staying late to finish urgent tasks etc }\end{array}$ \\
\hline
\end{tabular}

Source: Culled from teaching and assessing soft skills by K. Kechagias (2011) pages 83 and

\section{Appendix II: Original Draft}

\section{National Business and Technical Examinations Board (Nabteb) Benin City}

Dear Respondent,

This instrument is designed to elicit relevant information from you on "Validation of Modified Soft Skills Assessment Instrument (MOSSAI) for use in Nigeria. The essence is to provide useful information for decision making on inclusion of soft skills in the school curriculum.. The instrument is purely for academic purposes. Please note that your responses would be treated with utmost confidentiality. Thanking you in anticipation for your favourable response.

\section{Section A (Personal Profile)}

Please respond by placing a tick $(\checkmark)$ where appropriate.

1. Name of School

2. Type of School: Public

3. Gender Male

Private Female

\section{Section B}

Below are statements that address some selected soft skills which you are to respond to in the form of rating scale with Very Teachable (VT), Teachable (T), Fairly Teachable (FT) and Not Teachable (NT). Please read carefully each of the under-listed statements and respond by placing a tick ( ) that best suits each of the statement along the continuum. 


\begin{tabular}{|c|c|c|c|c|c|}
\hline $\mathrm{S} / \mathrm{N}$ & $\begin{array}{c}\text { SOFT SKILLS } \\
\end{array}$ & VT & $\mathrm{T}$ & $\mathrm{F}$ & NT \\
\hline 1. & Readily accepting responsibilities & & & & \\
\hline 2. & Zealous in performing one's duties & & & & \\
\hline 3. & Creativity on the job & & & & \\
\hline 4. & Delegating duties to right persons & & & & \\
\hline 5. & Diligence in supervision & & & & \\
\hline 6. & Punctuality at work & & & & \\
\hline 7. & Enthusiasm at work & & & & \\
\hline 8. & Moral integrity on the job & & & & \\
\hline 9. & Devotion to duty & & & & \\
\hline 10 & Eager to learn & & & & \\
\hline 11. & Goals setting & & & & \\
\hline 12. & Job security & & & & \\
\hline 13. & Job enlargement & & & & \\
\hline 14. & Job rotation & & & & \\
\hline 15. & Reinforcement & & & & \\
\hline 16. & Mastery of job content & & & & \\
\hline $\mathrm{S} / \mathrm{N}$ & SOFT SKILLS & VT & $\mathrm{T}$ & $\mathrm{F}$ & NT \\
\hline 17. & Being readily available at work & & & & \\
\hline 18. & Efficiency & & & & \\
\hline 19. & Effectiveness & & & & \\
\hline 20. & Time management & & & & \\
\hline 21. & Good work ethics & & & & \\
\hline 22. & Observance of school rules and regulations & & & & \\
\hline 23. & Loyalty to duty & & & & \\
\hline 24. & Patience at work & & & & \\
\hline 25. & Contentment & & & & \\
\hline 26. & Speaking skill & & & & \\
\hline 27. & Reading skill & & & & \\
\hline 28. & Writing skill & & & & \\
\hline 29. & Body language & & & & \\
\hline 30. & Quantity of resources & & & & \\
\hline 31. & Quality of resources & & & & \\
\hline 32. & Allocation of resources & & & & \\
\hline 33. & Implementation & & & & \\
\hline 34. & Supervision & & & & \\
\hline 35. & Coordination & & & & \\
\hline 36. & Evaluation & & & & \\
\hline 37. & Feedback & & & & \\
\hline 38. & Tolerance & & & & \\
\hline 39. & Cooperation & & & & \\
\hline 40. & Leadership style & & & & \\
\hline 41. & Followership traits & & & & \\
\hline 42. & Administrative support & & & & \\
\hline 43. & Operational support & & & & \\
\hline 44. & On the job training & & & & \\
\hline 45. & Mentoring & & & & \\
\hline 46. & Providing feedback & & & & \\
\hline 47. & Insightfulness & & & & \\
\hline 48. & Ability to Recall & & & & \\
\hline 49. & Turn challenges to opportunities & & & & \\
\hline 50. & Turn weaknesses to strength & & & & \\
\hline 51. & Seek for improved knowledge & & & & \\
\hline 52. & Seek for advice & & & & \\
\hline 53. & Polite requests & & & & \\
\hline 54. & Confidence in the ability of others & & & & \\
\hline 55. & Embracing changes & & & & \\
\hline 56. & Observance of ser goals & & & & \\
\hline 57. & Observance of new rules and regulations at workplace & & & & \\
\hline 58. & Embracing new knowledge & & & & \\
\hline 59. & Perseverance & & & & \\
\hline 60 & Fact finding & & & & \\
\hline 61. & Carefulness & & & & \\
\hline 62. & Diligence & & & & \\
\hline 63. & Admitting one's own limitations & & & & \\
\hline
\end{tabular}




\section{Section C}

Suggested below are methods of teaching the above selected soft skills. Please indicate in the form of Very appropriate (VA), Appropriate (A), Not Appropriate (NA).

\begin{tabular}{|c|c|c|c|c|}
\hline $\mathrm{S} / \mathrm{N}$ & SUGGESTED METHODS OF TEACHING SOFT SKILLS & VA & A & NA \\
\hline 1. & Direct instruction & & & \\
\hline 2. & Demonstration method & & & \\
\hline 3. & Lecture method & & & \\
\hline 4. & Simulation method & & & \\
\hline 5. & Discussion method & & & \\
\hline 6. & Rote memorization & & & \\
\hline 7. & Self discovery method & & & \\
\hline 8. & Questioning method & & & \\
\hline 9. & Interviewing method & & & \\
\hline 10. & Project method & & & \\
\hline 11. & Mapping method & & & \\
\hline 12. & Cooperative learning & & & \\
\hline 13. & Reflection & & & \\
\hline 14. & Pictorial method & & & \\
\hline
\end{tabular}

\section{Section D}

Read carefully the suggested assessment methods by which the above selected soft skills can be assessed. Please indicate in the form of Very appropriate (VA), Appropriate (A), Not Appropriate (NA).

\begin{tabular}{|c|c|c|c|c|}
\hline $\mathrm{S} / \mathrm{N}$ & SUGGESTED ASSESSMENT METHODS & VA & A & NA \\
\hline 1. & Objective tests & & & \\
\hline 2. & Essay tests & & & \\
\hline 3. & Practical tests & & & \\
\hline 4. & Speed tests & & & \\
\hline 5. & Checklists & & & \\
\hline 6. & Questionnaires & & & \\
\hline 7 & Interviews & & & \\
\hline 8. & Rating scales & & & \\
\hline 9. & Observations & & & \\
\hline 10. & Portfolio & & & \\
\hline 11. & Assignments & & & \\
\hline
\end{tabular}

\section{Appendix III: Final Version}

\section{National Business and Technical Examinations Board (Nabteb) Benin City}

Dear Respondent,

This instrument is designed to elicit relevant information from you on "Validation of Modified Soft Skills Assessment Instrument (MOSSAI) for use in Nigeria. The essence is to provide useful information for decision making on inclusion of soft skills in the school curriculum.. The instrument is purely for academic purposes. Please note that your responses would be treated with utmost confidentiality. Thanking you in anticipation for your favourable response.

\section{Section A (Personal Profile)}

Please respond by placing a tick $(\checkmark)$ where appropriate.

1. Name of School

2. Type of School: Public

3. Gender Male

Private

Female

\section{Section B}

Below are statements that address some selected soft skills which you are to respond to in the form of rating scale with Very Teachable (VT), Teachable (T), Fairly Teachable (FT) and Not Teachable (NT). Please read carefully each of the underlisted statements and respond by placing a tick () that best suits each of the statement along the continuum. 


\begin{tabular}{|c|c|c|c|c|c|}
\hline $\mathrm{S} / \mathrm{N}$ & SOFT SKILLS & VT & $\mathrm{T}$ & $\mathrm{F}$ & NT \\
\hline A & Commitment to duty & & & & \\
\hline 1. & Punctuality at work & & & & \\
\hline 2 & Moral integrity on the job & & & & \\
\hline 3. & Being readily available at work & & & & \\
\hline 4 & Loyalty to duty & & & & \\
\hline 5. & Efficiency & & & & \\
\hline 6. & Effectiveness & & & & \\
\hline 7. & Devotion to duty & & & & \\
\hline 8. & Diligence in supervision & & & & \\
\hline 9. & Enthusiasm at work & & & & \\
\hline 10. & Zealous in performing one's duties & & & & \\
\hline 11 & Good work ethics & & & & \\
\hline 12. & Eager to learn & & & & \\
\hline 13. & Contentment & & & & \\
\hline 14. & Creativity in the job & & & & \\
\hline 15. & Delegating duties to right persons & & & & \\
\hline 16. & Observance of school rules and regulations & & & & \\
\hline 17. & Patience at work & & & & \\
\hline 18. & Mastery of job content & & & & \\
\hline $\mathrm{B}$ & Attending to responsibilities & & & & \\
\hline 19. & On the job training & & & & \\
\hline 20. & Operational support & & & & \\
\hline 21. & Providing feedback & & & & \\
\hline 22 & Administrative support & & & & \\
\hline 23. & Mentoring & & & & \\
\hline 24. & Insightfulness & & & & \\
\hline 25. & Leadership style & & & & \\
\hline 26. & Followership traits & & & & \\
\hline 27. & Turn challenges to opportunities & & & & \\
\hline 28. & Ability to Recall & & & & \\
\hline 29. & Seek for improved knowledge & & & & \\
\hline 30. & Turn weaknesses to strength & & & & \\
\hline 31. & Feedback & & & & \\
\hline 32. & Tolerance & & & & \\
\hline 33. & Cooperation & & & & \\
\hline C. & Adaptability & & & & \\
\hline 34. & Embracing changes & & & & \\
\hline 35. & Carefulness & & & & \\
\hline 36. & Fact finding & & & & \\
\hline 37. & Observance of set goals & & & & \\
\hline 38. & Observance of new rule and regulations at workplace & & & & \\
\hline 39. & Perseverance & & & & \\
\hline 40. & Confidence in the ability of others & & & & \\
\hline 41. & Diligence & & & & \\
\hline 42. & Embracing new knowledge & & & & \\
\hline D. & Resources management skills & & & & \\
\hline 43. & Quantity of resources & & & & \\
\hline 44. & Quality of resources & & & & \\
\hline 45. & Allocation of resources & & & & \\
\hline 46. & Implementation & & & & \\
\hline E. & Motivation & & & & \\
\hline 47. & Job rotation & & & & \\
\hline 48. & Job enlargement & & & & \\
\hline 49. & Reinforcement & & & & \\
\hline 50. & Job security & & & & \\
\hline
\end{tabular}




\section{Section C}

Suggested below are methods of teaching the above selected soft skills. Please indicate in the form of Very appropriate (VA), Appropriate (A), Not Appropriate (NA).

\begin{tabular}{|c|c|c|c|c|}
\hline $\mathrm{S} / \mathrm{N}$ & SUGGESTED METHODS OF TEACHING SOFT SKILLS & VA & A & NA \\
\hline 1. & Direct instruction & & & \\
\hline 2. & Demonstration method & & & \\
\hline 3. & Lecture method & & & \\
\hline 4. & Simulation method & & & \\
\hline 5. & Discussion method & & & \\
\hline 6. & Rote memorization & & & \\
\hline 7. & Self discovery method & & & \\
\hline 8. & Questioning method & & & \\
\hline 9. & Interviewing method & & & \\
\hline 10. & Project method & & & \\
\hline 11. & Mapping method & & & \\
\hline 12. & Cooperative learning & & & \\
\hline 13. & Reflection & & & \\
\hline 14. & Pictorial method & & & \\
\hline
\end{tabular}

\section{Section D}

Read carefully the suggested assessment methods by which the above selected soft skills can be assessed. Please indicate in the form of Very appropriate (VA), Appropriate (A), Not Appropriate (NA).

\begin{tabular}{|c|c|c|c|c|}
\hline $\mathrm{S} / \mathrm{N}$ & SUGGESTED ASSESSMENT METHODS & VA & A & NA \\
\hline 1. & Objective tests & & & \\
\hline 2. & Essay tests & & & \\
\hline 3. & Practical tests & & & \\
\hline 4. & Speed tests & & & \\
\hline 5. & Checklists & & & \\
\hline 6. & Questionnaires & & & \\
\hline 7 & Interviews & & & \\
\hline 8. & Rating scales & & & \\
\hline 9. & Observations & & & \\
\hline 10. & Portfolio & & & \\
\hline 11. & Assignments & & & \\
\hline
\end{tabular}

(20)

\section{REFERENCES}

[1] R. Shakir, Soft skills at the Malaysian institutes of higher learning. Asia Pacific Educ. Rev. Vol.10, 309 - 315, 2009.

[2] Education Equals Economics (E3) Alliance, Ready or Not? Professional Skills into 21st Century to Education, Online available from http;//www.atomiclearning.com

[3] K. Kechagias, Teaching and assessing soft skills, 1st Second Chance School of Thessaloniki (Neapolis), Thessaloniki, 2001.

[4] G.P. Bunk, Teaching competence in initial and continuing vocational training in the Federal Republic of Germany,
CEDEFOP, Vol.1, 9- 14, 1994.

[5] G.R. Nabi, Graduate employment and underemployment: Opportunity for skill use and career experiences amongst recent business graduates, Journal of Education and Training, Vol.45, No.7, 371-382, 2003.

[6] R. Crosbie, Learning the soft skills of leadership, industrial and commercial training, Vol.37, Issue 1, 45-51, 2005.

[7] Gordon, M, Co Meath VEC, Youthreach Soft Skills Framework, Online available from http;//www.youtreac.ic

[8] O.A. Aworanti, Integration of soft skills assessment into public examining in technical and vocational education (TVE). Paper presented at: The 31st Annual Conference of Association of Educational Assessment in Africa (AEAA); 2012 August 12 to 16, Botswana, Africa. 
[9] L. Lee, T. Lee, Investigating soft skills for success in the workforce: Perceptions of elementary school teachers. Journal of International Review of Social Sciences and Humanities, Vol. 1, No.2, 140-149, 2011.

[10] F. N. Kerlinger, H.B. Lee, Foundations of behavioural research, Harcourt College Publishers, Philadelphia, 2000.
[11] C.A. Mertler, R.A. Vannatta, Advanced and multivariate statistical methods: Practical application and interpretation, Pyrezak Publishing, Glendale, 2005.

[12] D.D. Curtis, International perspectives on generic skills, generic in vocational education and training, Research readings, Australia; NCVER, 19-37, 2004. 